\section{Initial antiretroviral therapy in a 20-year observational cohort of patients followed at a reference center in the City of São Paulo, Brazil}

\section{Terapia antiretroviral inicial (ARV) em uma coorte observacional de 20 anos de pacientes em seguimento em um centro de referência na cidade de São Paulo, Brasil}

Emily A. C. Ruiz'

Marta Ramalho'

Mariza V. Tancredi'

Jean P. Moatti"

Ana L. C. Monteiro'

Mylva Fonsi'

Julien Chauveau"

' São Paulo STD/Aids Training and Reference Center

"Research Unit UMR912 "Economic \& Social Sciences, Health Systems \& Societies", INSERM, Marseilles, France and IRD, Aix Marseilles Université, Marseilles, France. Southeastern Health Regional Observatory (ORS-PACA), Marseilles, France

Funding: The work was supported by grants from the French National Agency for Research on AIDS and Viral Hepatitis (Agence nationale de recherches sur le sida et les hepatitis virales Ref:: $\mathrm{SF} / \mathrm{NA} / \mathrm{n}^{\circ} 1616$ ) and funds from Centro de Referência e Treinamento DST/Aids, São Paulo, Brazil. Correspondence: Emily A C Ruiz. Centro de Referência e Treinamento DST/AIDS, Vigilância Epidemiológica, Sala 115. Rua Santa Cruz 81, SP, Brasil CEP 04121-000. E-mail: emily@crt.saude.sp.gov.br

\section{Abstract}

Introduction: Production and free universal access to ART for patients with HIV/ Aids were responsible for a major fall in morbidity-mortality in Brazil. Objective: To describe antiretroviral treatment at the São Paulo STD/Aids Training and Reference Center. Methods: Cross-sectional analysis of the characteristics of the first treatment with antiretroviral drugs of a retrospective cohort of patients 13 years and over, enrolled at the Reference Center, 1985-2005, described by frequency tables and graphs. Results: 4,191 patients were described. The most frequent initiation period was 1999$2003 ; 82.7 \%$ of patients were treatment naïve. Monotherapy prevailed until 1995, the peak of double therapy was 1996-98, and 1999-2005 was characterized by triple therapy. Regarding triple therapy, regimens with protease inhibitors accounted for 1,462 (34.9\%) of all first prescriptions. The combination AZT, 3TC and EFV was the most frequently prescribed regimen $(47.4 \%)$ in 2005. Conclusions: This descriptive study may enable more in depth analyses on the factors involved in the treatment patients with HIV/AIDS.

Keywords: Antiretroviral treatment. Treatment. HIV. Aids. Epidemiology. ART. 


\section{Resumo}

Introdução: A produção e o acesso gratuito e universal aos antiretrovirais (ARV) foram responsáveis pela grande queda na morbi-mortalidade por HIV/Aids no Brasil. Objetivo: descrever o tratamento com ARV no Centro de Referência e Treinamento DST/AIDS São Paulo. Método: Análise longitudinal das características do primeiro tratamento com antirretrovirais de uma coorte retrospectiva de pacientes com 13 anos e mais, matriculados no Centro de Referência, 1985-2005, descrito através de tabelas de frequência e gráficos. Resultados: Foram descritos 4191 pacientes. A maior concentração de iniciação foi no período $1999-2003 ; 82,7 \%$ dos pacientes eram virgens de tratamento. A monoterapia prevaleceu até 1995, o pico da terapia dupla foi 1996-1998, e o período de 1999 a 2005 se caracterizou pela prescrição de terapia tripla. Na terapia tripla, esquemas com inibidores de protease corresponderam a 1.462 $(34,9 \%)$ de todas as prescrições iniciais. A combinação AZT, 3TC e EFV foi o esquema mais frequentemente prescrito $(47,4 \%) \mathrm{em}$ 2005. Conclusões: Esse estudo descritivo possibilita o desenvolvimento de análises mais profundas sobre os fatores envolvidos no tratamento de pacientes com HIV/AIDS.

Palavras-chave: Tratamento antiretroviral. Tratamento. HIV. Aids. Epidemiologia. ARV.

\section{Introduction}

Production and free and universal access to Antiretroviral Therapy (ART) for patients with HIV/AIDS as of 1991 in Brazil have been associated with decrease in mortality rates, changes in hospitalization rates and morbidity and treatment of associated opportunistic infections ${ }^{1,2}$. According to Guibu et al., $56.7 \%$ of patients diagnosed in 1998 lived up to 9 years as did $63.9 \%$ of those diagnosed in $1999^{3}$. ARV treatment at a STD/AIDS Training and Reference Center in the city of São Paulo has also resulted in a general increase in patient survival after the 1996 introduction of triple therapy ${ }^{4}$.

Despite the well-established association between treatment with antiretroviral drugs and increase in survival, less is known on the association of certain patient factors, such as age and gender ${ }^{5}$, or behavioral ones such as injecting drug use ${ }^{6}$, which have been associated with variability in survival times. Many of the studies on outcomes related to antiretroviral drug treatment, mainly HAART, are clinical studies such as those carried out by different Collaboration groups. Examples are the ART Cohort Collaboration ${ }^{7}$ and the When to Start Consortium ${ }^{8}$.

The detailed description of patients and of ART regimens received at the CRTDST/Aids in the period from 1985 to 2005 presented in our study aims to further contribute to the better understanding of the characteristics of ART and the factors that may influence it in Brazil, and identify and suggest lines of investigation to deepen knowledge on the therapeutic approach to fight the HIV/AIDS epidemic.

\section{Methods}

This exploratory study relates to data collected on a retrospective cohort of HIVinfected individuals, 13 years old and over, with and without AIDS, enrolled at the Centro de Referência e Treinamento DST/ Aids São Paulo (CRT), and who were on antiretroviral drug treatment (ART) from 1985 to 2005. The present paper is a cross- 
sectional analysis of the characteristics of 4,191 patients of this cohort and their first known ART prescription.

Data were collected by nurses and physicians of the CRT Disease Surveillance Department, during disease reporting routine follow-up of patient medical charts. From 1998 to 2005, the Disease Surveillance team routine included collecting data on treatment.

Patients were classified as AIDS according to the case definition criteria adopted by the Brazilian National STD/Aids Program, whose main differences with international/ CDC criteria relate to inclusion of individuals with CD4<350 and RJ/Caracas ${ }^{9}$ criteria for classifying cases.

An initial descriptive analysis of the study population was performed using frequency tables and graphs for categorical variables. Data were divided into epidemiological-demographic, clinical-laboratory and treatment variables for analysis.

The clinical-laboratory description was based on case definition criteria and CD4 lymphocyte count (CD4) and Viral Load (VL) values. CD4 and VL dates and counts were used to determine CD4 and VL nearer to: first known HIV positive test, diagnosis of AIDS, beginning of each ART regimen, and death.

ART prescription dates were used to determine the duration of the first treatment; use of ART before the first known date of regimen allowed classifying patients into treatment-naive or non-naive; dates of enrollment, first appointment and beginning of treatment allowed classifying patients who began treatment at CRT or previous to enrollment at CRT at another service; dates of first HIV test, of Aids diagnosis and of beginning of treatment allowed classifying status as HIV without AIDS or AIDS; dates of Aids diagnosis, of first prescription, and of enrollment were used to calculate time between the diagnosis of Aids and beginning of treatment; the same previous variables were used for patients defined as CRT.

Treatments were described using drug classes (Protease Inhibitor-PI, Nucleotide
Reverse Transcriptase Inhibitor-NRTI, and Non Nucleotide Reverse Transcriptase Inhibitor-NNRTI) and individual drugs.

Individuals extracted from the referred 1985-2005 cohort whose treatment began as of the date in which they met AIDS case definition criteria (2,546 patients) were used to perform a more detailed analysis. The rationale was to use Brazilian AIDS Treatment Guidelines in effect up to 2007 that determined only cases defined as AIDS should initiate treatment. A cross-sectional analysis of the characteristics of individuals who met the above AIDS definition criteria and who began HAART -1,661 individuals - was performed, describing patients according to having initiated treatment with or without a PI (that is with a NNRTI). The event "HAART with PI" was chosen as the dependent variable for the analysis. The independent variables were demographic, epidemiological and clinical-laboratory characteristics.

The statistical analysis of data on initial treatment with HAART used exploratory techniques to check the patterns of distribution and trends of the main variables. Following, a bivariate analysis was performed to check for the associations among variables. Chi-square tests $\left(\chi^{2}\right)$ for difference of proportions were used. Odds ratio with a $95 \%$ confidence interval was used to estimate associations. Multivariate analysis was carried out to estimate the joint effects of independent variables, using logistic regression models. The final model included variables with a $\mathrm{p}<0.25$ in the bivariate analysis. The model was adjusted through the step-by-step progressive procedure, and the inclusion of variables followed a growing order of $O R$ values. The likelihood ratio test was used to assess the importance of the variables for the final model, considering $\mathrm{p}<0.05$. The STATA 10.0 statistical package was used to store and analyze data.

\section{Ethical Aspects}

The study was submitted and approved by the CRT-DST/AIDS research ethics board 
and all measures to protect confidentiality of information were taken.

\section{Results}

The disease surveillance ART database, comprised of 4,191 individuals, is estimated to be approximately $75 \%$ of the total number of patients on ART at CRT. Table 1 summarizes the characteristics of patients and of their initial ART.

There is a predominance of men, individuals between 30 and 49 years of age, white, with over 8 years of schooling, in the population studied. The distribution of exposure category shows a predominance of men who have sex with men (MSM) and heterosexuals.

Regarding median values and ranges of CD4 and VL, despite a smaller number

Table 1 - Characteristics related to initial ARV treatment at CRT-DST/Aids, SP, Brazil, 1985-2005.

Tabela 1 - Características relacionadas ao tratamento inicial com ARV no CRT-DST/Aids, SP, Brasil, 1985-2005.

\begin{tabular}{|c|c|c|}
\hline & $\mathrm{N}$ & $\%$ \\
\hline \multicolumn{3}{|l|}{ GENDER } \\
\hline Men & 3,029 & 72.3 \\
\hline Women & 1,162 & 27.7 \\
\hline \multicolumn{3}{|l|}{ AGE GROUP $\quad$ (MEDIAN=34; RANGE 15-76) } \\
\hline 15-29 YEARS & 1,091 & 26.0 \\
\hline $30-49$ & 2,827 & 67.5 \\
\hline $50+$ & 273 & 6.5 \\
\hline \multicolumn{3}{|l|}{ RACE/COLOR } \\
\hline White & 3,013 & 71.9 \\
\hline Black & 1,094 & 26.1 \\
\hline Other & 84 & 2.0 \\
\hline \multicolumn{3}{|l|}{ SCHOOLING } \\
\hline Illiterate & 24 & 0.6 \\
\hline $1-8$ years & 1,328 & 31.7 \\
\hline$>8$ years & 2,629 & 62.7 \\
\hline Unknown & 210 & 5.0 \\
\hline \multicolumn{3}{|l|}{ EXPOSURE CATEGORY } \\
\hline Heterossexuais & 1,633 & 38.9 \\
\hline Men who have sex with men & 1,823 & 43.5 \\
\hline Intravenous Drug Users & 491 & 11.7 \\
\hline Hemophilia/Transfusion & 8 & 0.3 \\
\hline Unknown & 236 & 5.6 \\
\hline DEATHS & 508 & 12.1 \\
\hline \multicolumn{3}{|l|}{ Clinical Laboratory Variables } \\
\hline \multicolumn{3}{|l|}{ AIDS DEFINITION CRITERIA } \\
\hline CD4 & 1,682 & 40.1 \\
\hline $\mathrm{CDC}$ & 611 & 14.6 \\
\hline RJ/CARACAS & 522 & 12.5 \\
\hline Other & 213 & 17.1 \\
\hline Not AIDS & 456 & 10.9 \\
\hline Unknown & 707 & 16.9 \\
\hline \multicolumn{3}{|l|}{ CD4 (cells/mm3) } \\
\hline CD4 nearest to HIV positive diagnosis (MEDIAN=615; RANGE 40-1,185) & 345 & - \\
\hline (MEDIAN=291; RANGE 153-426) & 3,259 & - \\
\hline (MEDIAN=313; RANGE 164-492) & 3,604 & - \\
\hline (MEDIAN=91; RANGE 21-266) & 567 & - \\
\hline
\end{tabular}


Table 1 - Characteristics related to initial ARV treatment at CRT-DST/Aids, SP, Brazil, 1985-2005. (cont.)

Tabela 1 - Características relacionadas ao tratamento inicial com ARV no CRT-DST/Aids, SP, Brasil, 1985-2005. (cont.)

\begin{tabular}{|c|c|c|c|}
\hline & & $\mathrm{N}$ & $\%$ \\
\hline \multicolumn{4}{|l|}{$\overline{\mathrm{VL}}$} \\
\hline VL nearest to HIV positive diagnosis & $($ MEDIAN=9,100; RANGE 67-700,000) & 216 & - \\
\hline VL nearest to AIDS diagnosis & $($ MEDIAN=22,000; RANGE 58-15,000,000) & 2,157 & - \\
\hline$V L$ nearest to $A R T$ initiation & (MEDIAN=17,450; RANGE 57-15,000,000) & 2,346 & - \\
\hline VL nearest to death & (MEDIAN=85500; RANGE 82-15,000,000) & 404 & - \\
\hline \multicolumn{4}{|l|}{ Treatment Variables } \\
\hline \multicolumn{4}{|l|}{ INITIAL COHORT } \\
\hline $1985-90$ & & 18 & 0.4 \\
\hline $1991-95$ & & 368 & 8.8 \\
\hline $1996-98$ & & 1,622 & 38.7 \\
\hline 1999-03 & & 1,830 & 43.7 \\
\hline 2004-05 & & 353 & 8.4 \\
\hline \multicolumn{4}{|l|}{ BASELINE STATUS } \\
\hline Naive & & 3,465 & 82.7 \\
\hline Non-Naive & & 726 & 17.3 \\
\hline \multicolumn{4}{|l|}{ STATUS AT CRT } \\
\hline Began Treatment at CRT & & 3.400 & 81.1 \\
\hline Began Treatment elsewhere & & 791 & 18.9 \\
\hline \multicolumn{4}{|l|}{ HIV/AIDS STATUS } \\
\hline HIV to endpoint & & 456 & 10.9 \\
\hline AIDS $\leq$ Initial Treatment & & 2,546 & 60.7 \\
\hline AIDS> Initial Treatment & & 1,189 & 28.4 \\
\hline \multicolumn{4}{|c|}{ TIME BETWEEN AIDS DIAGNOSIS AND ART INITIATION (days) } \\
\hline $0-30$ & & 761 & 18.2 \\
\hline $31-60$ & & 400 & 9.5 \\
\hline $61-120$ & & 284 & 6.8 \\
\hline $121-365$ & & 353 & 8.4 \\
\hline $366-730$ & & 232 & 5.5 \\
\hline$>730$ & & 516 & 12.3 \\
\hline Initial Treatment before AIDS & & 1,189 & 28.4 \\
\hline HIV to endpoint & & 456 & 10.9 \\
\hline TIME BETWEEN AIDS AND ART INITIAT & N-CRT PATIENTS (days) & 3,083 & \\
\hline $0-30$ & & 675 & 21.9 \\
\hline $31-60$ & & 359 & 11.7 \\
\hline $61-120$ & & 257 & 8.3 \\
\hline $121-365$ & & 312 & 10.1 \\
\hline $366-730$ & & 194 & 6.3 \\
\hline$>730$ & & 278 & 9.0 \\
\hline Initial Treatment before AIDS & & 709 & 23.0 \\
\hline HIV to endpoint & & 299 & 9.7 \\
\hline \multicolumn{4}{|l|}{ DURATION OF INITIAL TREATMENT (days) } \\
\hline $1-30$ & & 312 & 7.5 \\
\hline $31-60$ & & 237 & 5.7 \\
\hline $61-120$ & & 372 & 8.8 \\
\hline $121-365$ & & 983 & 23.5 \\
\hline $366-730$ & & 856 & 20.4 \\
\hline$>730$ & & 1,431 & 34.1 \\
\hline
\end{tabular}


of values available near the HIV positive diagnosis, the highest CD4 medians were observed for tests performed nearest to this time period. Both CD4 nearest to AIDS diagnosis and $\mathrm{CD} 4$ nearest to ART initiation have median values below the $350 \mathrm{cell} / \mathrm{mm}^{3}$ level defined as a case definition criterion. The lowest median VL values were the ones nearest to HIV diagnosis and the highest near to AIDS diagnosis, with values at time of ART initiation between both values.

The population showed the highest concentration of initiation in the 1999-03 period, followed by the 1996-98 period.

Most of the patients analyzed were treatment naive $(82.7 \%)$ upon entering the study. Moreover, most individuals began their treatment at CRT (81.1\%).

Roughly $89 \%$ of the group was defined as AIDS cases during the follow-up period, most of which $(60.7 \%)$ before beginning ART. Additionally, $10.9 \%$ of patients remained free of AIDS throughout the treatment period.

As to time between AIDS diagnosis and initiation of ART, roughly $34.5 \%$ began up to 4 months after diagnosis; $17.8 \%$ of patients began treatment after 1 year of diagnosis. Among patients who began treatment after enrolling at CRT, a higher percentage of patients (41.9\%) began treatment up to 4 months after diagnosis and less (15.3\%) after 1 year of diagnosis. Regarding the duration of initial treatment, $7.5 \%$ remained 30 days or less on their first regimen, and $54.5 \%$ stayed one year or more on initial regimen.

Figure 1 sums up the main characteristics of ART according to classes of drugs, at the CRT-DST/Aids as of 1991, and Figure 2 shows ART as of 1994 describing PI or NNRTI drugs used.

Figure 1 shows a predominance of monotherapy up to 1994 when it began to decrease; double therapy peaked from 1996 to 1998, and the $1999-2005$ period was characterized by prescriptions of triple therapies. Regarding triple therapy in our study, 2NNRTI plus 1PI grew and remained fairly stable until 2002; 2NRTI plus 1NNRTI began to grow steadily as of 1999, surpassing the previous regimen between 2002 and 2003. Regimens with 2NRTI plus a PI accounted for 1,462 (34.9\%) of all first prescriptions.

Figure 2 shows that indinavir (IDV) was the main PI up to 1998, which decreased there on, albeit with a non negligible share until 2002; nelfinavir (NFV) had a major growth in the 1999-2000 period, and began

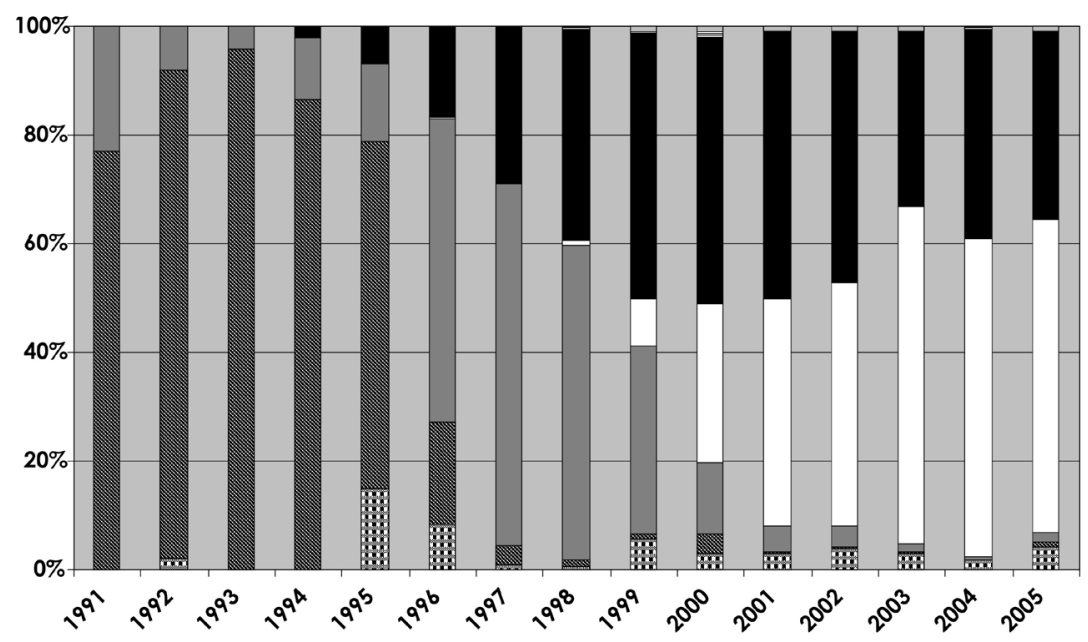

OOTHERS MONO $\square$ 2NRTI $\square$ 2NRTI+NNRTI $\square$ 2NRTI+PI 国 2NRTI+NNRTI+IP

Figure 1 - Main types of ART regimens by drug class at CRT-DST/Aids, São Paulo, Brazil, 19912005.

Figura 1 - Principais esquemas de ARV por classe de droga no CRT-DST/Aids, São Paulo, Brasil, 1991-2005. 


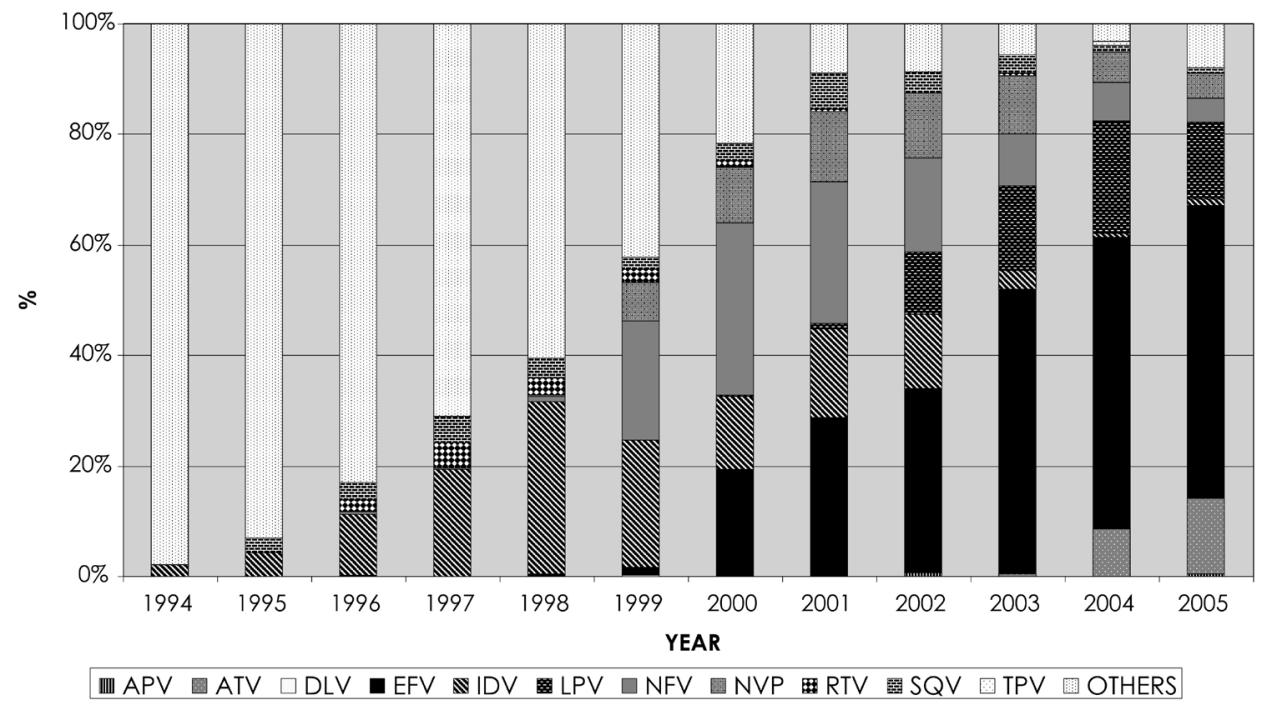

Figure 2 -Drugs combined with NRTI(2) in triple therapy at CRT-DST/Aids, SP. Brazil, 1994-2005. Figura 2 - Drogas associadas a ITRN (2) em terapia tripla no CRT-DST/Aids, SP, Brasil, 1994-2005

to decrease as of 2001. Still considering PI, lopinavir (LPV) grew at a slower pace beginning 2002, peaked in 2004 and began to decrease. Regarding NNRTI, undoubtedly efavirenz (EFV) was of the most prevalent use, growing steadily as of 2000 . Of total first prescriptions, 779 (18.6\%) were zidovudine (AZT) and didanosine (DDI), while 489 (11.7\%) were AZT, lamivudine (3TC) and EFV. The combination of AZT, 3TC and EFV was the most prescribed regimen in 2005 (47.4\%), followed by AZT, 3TC and lopinavir/ ritonavir (LPV/r) (10.4\%).

The group of patients who were defined as AIDS when beginning treatment comprised 2,546 patients. Of these, 1,661 were identified as having initiated treatment with Highly Active Antiretroviral Treatment (HAART), with a NRTI and, either a NNRTI or PI. Table 2 describes the 1,661 patients according to type of initial HAART treatment.

Among the 1,661 patients, there was also a predominance of men, patients over 30 years of age, white and with over 8 years of schooling. Regarding exposure category, however, there were more heterosexuals than men who have sex with men.

The main diagnosis period was 1997 to 2005, most patients were naive, and over $60 \%$ began treatment up to 120 days of AIDS diagnosis. In the NRTI without PI group, $78.1 \%$ of patients remained on their first treatment over one year, and this was the case for $88.3 \%$ of patients in the NRTI with PI subgroup.

The multivariate analysis by the logistic regression model according to factors associated with initiation with HAART plus $\mathrm{PI}$ and the independent variables described below are presented in Table 3 . The factors that presented an effect were: being male $\left[O R_{\mathrm{aj}}=1.4(95 \% \mathrm{CI} 1.1-1.8)\right]$, being an injecting drug user $\left[O R_{\mathrm{aj}}=1.2(95 \%\right.$ CI 1.1 - 1.8)], being on initial treatment over 365 days $\left[O R_{\mathrm{aj}}=2.2(95 \% \mathrm{CI} 1.1-4.4)\right]$ and not having died $\left[O R_{\mathrm{aj}}=2.6(95 \% \mathrm{CI} 1.8-3.7)\right]$ were associated with initiation of HAART with a PI. Having been diagnosed as AIDS after 1996 did not reveal an association $\left[O R_{\mathrm{aj}}=0.3(95 \%\right.$ CI $\left.0.2-0.4)\right]$.

\section{Discussion}

An important aspect of the present operational research-based study is the description of the first treatment of a large cohort of patients on ART with a long-term follow-up in Brazil. With the exception of the Antiretroviral Therapy Cohort Collaboration $^{10}$ that followed 20,739 individuals 
Table 2 - Characteristics related to initial HAART treatment of patients at CRT-DST/Aids, São Paulo, Brazil, 1985-2005. Tabela 2 - Características relacionadas ao tratamento inicial com TARV de pacientes do CRT-DST/Aids, São Paulo, Brasil, 19852005.

\begin{tabular}{|c|c|c|c|c|}
\hline \multirow{3}{*}{ Epidemiological and demographic variables } & \multicolumn{2}{|c|}{ HAART } & \multirow{3}{*}{$\begin{array}{c}\text { Total } \\
(\mathrm{n}=1,661) \\
\mathrm{n}(\%)\end{array}$} & \multirow[b]{3}{*}{$p$} \\
\hline & $\begin{array}{l}\text { without PI } \\
(\mathrm{n}=571)\end{array}$ & $\begin{array}{l}\text { with PI } \\
(\mathrm{n}=1,090)\end{array}$ & & \\
\hline & $\mathrm{n}(\%)$ & $\mathrm{n}(\%)$ & & \\
\hline Gender & & & & 0.014 \\
\hline Men & $403(70.6)$ & $830(76.1)$ & $1,233(74.2)$ & \\
\hline Women & $168(29.4)$ & $260(23.9)$ & $428(25.8)$ & \\
\hline Age group at AIDS dignosis & & & & 0.368 \\
\hline up to 30 years & $153(26.8)$ & $270(24.8)$ & $423(25.5)$ & \\
\hline$>30$ years & $418(73.2)$ & $820(75.2)$ & $1,238(74.5)$ & \\
\hline Race / color & & & & 0.162 \\
\hline White & $385(67.4)$ & $784(71.9)$ & $1,169(70.4)$ & \\
\hline Black & $174(30.5)$ & $286(26.2)$ & $460(27.7)$ & \\
\hline Other & $12(2.1)$ & $20(1.8)$ & $32(1.9)$ & \\
\hline Schooling & & & & 0.142 \\
\hline Illiterate & $6(1.1)$ & $7(0.6)$ & $13(0.8)$ & \\
\hline $1-8$ years & $150(26.3)$ & $318(29.2)$ & $468(28.2)$ & \\
\hline$>8$ years & $376(65.8)$ & $715(65.6)$ & $1,091(65.7)$ & \\
\hline Unknown & $39(6.8)$ & $50(4.6)$ & $89(5.4)$ & \\
\hline Exposure category & & & & 0.044 \\
\hline Heterossexuals & $287(50.3)$ & $504(46.2)$ & $791(47.6)$ & \\
\hline Men who have sex with men & $236(41.3)$ & $453(41.6)$ & $689(41.5)$ & \\
\hline Intravenous Drug Users & $48(8.4)$ & $133(12.2)$ & $181(10.9)$ & \\
\hline Aids diagnosis period & & & & $<0.001$ \\
\hline $1985-1996$ & $24(4.2)$ & $155(14.2)$ & $179(10.8)$ & \\
\hline $1997-2005$ & $547(95.8)$ & $935(85.8)$ & $1,482(89.2)$ & \\
\hline Baseline status & & & & 0.176 \\
\hline Non-naive & $102(17.9)$ & $225(20.6)$ & 327 (19.7) & \\
\hline Naive & $469(82.1)$ & $865(79.4)$ & $1,334(80.3)$ & \\
\hline Median CD4+ count (cells/mm³) & & & & 0.709 \\
\hline CD4+ nearest to AIDS diagnosis & $275(151-372)^{*}$ & $204(90-368)^{*}$ & $230(106-369)$ & \\
\hline CD4+ nearest to ART initiation & $245(144-332)^{*}$ & $200(90-360)^{*}$ & $216(104-348)$ & \\
\hline CD4+ nearest to death & $114(39-299)^{*}$ & $83(23-212)^{*}$ & $86(25-237)$ & \\
\hline $\begin{array}{l}\text { Time between AIDS diagnosis and ART initiation } \\
\text { (days) }\end{array}$ & & & & 0.435 \\
\hline $0-60$ & $298(52.2)$ & $609(55.9)$ & $907(54.6)$ & \\
\hline $61-120$ & $66(11.6)$ & $104(9.5)$ & $170(10.2)$ & \\
\hline $121-365$ & $73(12.8)$ & $131(12.0)$ & $204(12.3)$ & \\
\hline$>365$ & $134(23.5)$ & $246(22.6)$ & $380(22.9)$ & \\
\hline Duration of initial treatment (days) & & & & $<0.001$ \\
\hline $1-60$ & $17(3.0)$ & $28(2.6)$ & $45(2.7)$ & \\
\hline $61-120$ & $22(3.9)$ & $22(2.0)$ & $44(2.6)$ & \\
\hline $121-365$ & $86(15.1)$ & $78(7.2)$ & $164(9.9)$ & \\
\hline$>365$ & $446(78.1)$ & $962(88.3)$ & $1,408(84.8)$ & \\
\hline Death & & & & $<0.001$ \\
\hline Yes & $59(10.3)$ & $201(18.4)$ & $260(15.7)$ & \\
\hline No & $512(89.7)$ & $889(81.6)$ & $1401(84.3)$ & \\
\hline
\end{tabular}

* - interquartile range $25 \%-75 \%$ 
Tabela 3 - Análise bivariada e multivariada dos fatores associados a TARV com uso de IP, para pacientes do CRT-DST/Aids, São Paulo, Brasil, 1985-2005.

Table 3 - Bi and multivariate analysis of factors associated with HAART using PI, of patients of CRT-DST/Aids, São Paulo, Brazil, 1985 a 2005.

\begin{tabular}{|c|c|c|c|c|c|c|}
\hline & ORcr & $\begin{array}{l}95 \% \mathrm{Cl} \\
\text { (ORcr) }\end{array}$ & $\mathrm{p}$ & ORadj & $\begin{array}{l}95 \% \mathrm{Cl} \\
\text { (ORadj) }\end{array}$ & $\mathrm{p}$ \\
\hline \multicolumn{7}{|l|}{ Gender } \\
\hline Women & 1 & - & - & 1 & - & - \\
\hline Men & 1.3 & $1.1-1.7$ & 0.014 & 1.4 & $1.1-1.8$ & 0.031 \\
\hline \multicolumn{7}{|l|}{ Exposure category } \\
\hline Heterossexuals & 1 & - & - & 1 & - & - \\
\hline Men who have sex with men & 1.1 & $0.9-1.3$ & 0.415 & 0.9 & $1.0-1.2$ & 0.047 \\
\hline Intravenous Drug Users & 1.6 & $1.1-2.3$ & 0.013 & 1.2 & $1.1-1.8$ & 0.038 \\
\hline \multicolumn{7}{|l|}{ Aids diagnosis period } \\
\hline $1985-1996$ & 1 & - & - & 1 & - & - \\
\hline $1997-2005$ & 0.2 & $0.1-0.4$ & $<0.001$ & 0.3 & $0.2-0.4$ & $<0.001$ \\
\hline \multicolumn{7}{|l|}{ Duration of initial treatment (days) } \\
\hline $1-60$ & 1 & - & - & 1 & - & - \\
\hline $61-120$ & 0.6 & $0.3-1.4$ & 0.247 & 0.7 & $1.1-4.2$ & 0.043 \\
\hline $121-365$ & 0.5 & $0.3-1.1$ & 0.084 & 0.8 & $1.1-3.7$ & 0.05 \\
\hline$>365$ & 1.3 & $1.2-2.4$ & 0.038 & 2.2 & $1.1-4.4$ & 0.018 \\
\hline \multicolumn{7}{|l|}{ Death } \\
\hline Yes & 1 & - & - & 1 & - & - \\
\hline No & 1.9 & $1.4-2.6$ & $<0.001$ & 2.6 & $1.8-3.7$ & $<0.001$ \\
\hline
\end{tabular}

OR cr: Crude odds ratio. OR adj: Adjusted odds ratio. Cl: $95 \%$ Confidence interval

from 95-03, other patient follow-up based studies found did not reach the total number of individuals (maximum of 2,605) or follow-up period (maximum 17 years) ${ }^{11}$ of the CRT group. Another important aspect of this study is to describe management at one of the STD/Aids services in Brazil, a country that has developed guidelines similar to developed countries in a developing country scenario.

The predominance of men, individuals over 30 years of age, white, with over 8 years of schooling in the group studied is similar to what is observed for the overall HIV/ Aids population seen at CRT. Likewise, our population is similar to patients described in other Brazilian studies, such as a study on gender differences in survival in an HIV/AIDS cohort in an outpatient clinic in São Paulo, also comprised mainly of men (71\%), most with over 8 years of schooling ${ }^{12}$; and to a study on survival of AIDS patients in Rio, also with a predominance of men $(67 \%)$, a mean age of 35 , although unlike our study, most patients in the Rio study had less than 8 years of schooling ${ }^{13}$. The fact that IDU comprised $20 \%$ of AIDS cases reported in the CRT disease surveillance database, while they represent $11.7 \%$ of patients on ART stands out. The reasons for this under representativeness should be better investigated. A study on survival benefit of HAART access, comparing IDU and MSM, observed that IDU were less likely to receive HAART, and even to have a CD4 or VL count test ${ }^{14}$. The findings of a meta-analysis on adherence to ART among IDU have suggested that HIV positive IDU tend to be inappropriately considered as less adherent, although among the studies analyzed in the meta-analysis, adherence among IDU reached levels similar to those 
reported in studies conducted with other risk groups ${ }^{15}$.

Having $40 \%$ of AIDS cases defined by $\mathrm{CD} 4$ value criteria $\left(<350\right.$ cells $\left./ \mathrm{mm}^{3}\right)$ reflects a trend we have observed at our service and in AIDS case reporting in general toward an increasing number of cases being reported based on CD4 count since this more sensitive definition entered Brazilian Case Definition criteria. The fact that most cases with AIDS are diagnosed as CD4 shows this lab parameter as a major tool for ART initiation and management of the condition. CD4 count nearest to ART initiation with median values below 350 cells $/ \mathrm{mm}$ may also translate a trend toward fulfilling national guidelines in effect that have established beginning treatment in individuals who fulfill criteria as AIDS cases ${ }^{16}$. On the other hand, a median VL of 22,000 copies/ml nearest to AIDS diagnosis and of 17,450 copies/ $\mathrm{ml}$ nearest to date of ART initiation did not reflect alignment with Brazilian treatment guidelines recommending ART initiation in patients with a VL below 100,000 copies/ ml. A study to assess outcomes of HAART from 97-2004, in Italy, found a median CD4 lymphocyte count of 411 cells/ml upon initial treatment ${ }^{17}$. In the ART Cohort Collaboration study (10), $49 \%$ of patients started HAART either with a CD4 count of less than 200 cells $/ \mathrm{ml}$ or with a diagnosis of AIDS.

The growth in the number of patients in treatment cohorts relates closely to the higher availability of ART and number of drugs, mainly as of 1996.

The fact that most of the patients followed began their treatment at CRT $(81.1 \%)$ and that the majority was treatment naive (82.7\%) upon entering the cohort somewhat indicates a favorable situation for beginning treatment. In a previous AIDS patient survival study in São Paulo, $77.8 \%$ of women with aids were treatment naïve as were $70.6 \%$ of men $^{13}$.

These patients, whether beginning treatment at CRT or not (28.4\% and $23.0 \%$ ), still had a high proportion of treatment beginning before they were defined as AIDS. Another aspect, although we did not find any data for comparison, are the fairly low percentages of patients beginning treatment up to one month of diagnosis ( $18.2 \%$ for total, $21.9 \%$ for CRT group). The factors involved in treatment postponement, including patient adherence, deserve future studies. A point that should be underscored is the duration of initial treatment, 30 days or less for $7.5 \%$ of individuals, and one year or more for $54.5 \%$ of patients. A study to estimate length of the first antiretroviral therapy regimen in an outpatient setting in São Paulo found that almost one third of patients were unable to maintain the same treatment for six months, and only $25 \%$ did not change their regimen during a one year follow-up ${ }^{18}$, which may be an indication of better adherence to treatment of CRT patients.

We should emphasize that it is difficult to judge quality of treatment based on time between AIDS diagnosis and treatment initiation or beginning treatment before AIDS diagnosis, given the long period covered by the study, in which many different factors played a role on treatment decisions, such as different AIDS case definitions, lab test criteria and development of different national treatment guidelines.

We can say that overall the pattern of both ART class and drugs observed in the study reflect the availability of the different drugs and guidelines in Brazil throughout time. In comparison to other studies, treatment periods described in a study on pattern of hazard of death during ART from 1984-2004 at John Hopkins, revealed mono/combination treatment characterized the Jan90-Dec94 period and HAART, the period beginning Jan95 ${ }^{19}$, showing differences between both settings are not very pronounced. In the 97-04 study in Italy the most common drugs were lamividine (85\%), zidovudine $(57 \%)$, stavudine $(37 \%)$, indinavir $(28 \%)$ and efavirenz $(20 \%)^{16}$. In the São Paulo outpatient study, (1996-2000), the most used regimen was zidovudine/ lamivudine/indinavir (26\%), followed by zidovudine/didanosine (17\%), and zidovudine/lamivudine/nelfinavir (13\%) ${ }^{17}$.

According to the general description of 
the HAART, AIDS-defined group of 1,661 patients, the choice of initial treatment with a NNRTI or PI does not seem to have been influenced by age group, race or schooling. The group also presented high percentages of treatment beginning up to 60 days after diagnosis and of patients who remained on initial treatment for over a year. An interesting association with initiation of HAART with a PI was pointed out by the exploratory techniques used to check the patterns of distribution and trends of the main variables. The reasons that would lead to the choice of PI for treating males and IDU, and the possibility of staying longer on a treatment or of fewer deaths when a PI was chosen are all issues that deserve to be better explored.

Although having used secondary routine service data to offer a real-world vision on patients on ART may have been an advantage, these kinds of data have several limitations. Uniform definitions on data collecting, and differences in data collecting methods and interpretation of information by different individuals are some of the main drawbacks. While the long period the study refers to is one of its highlights, it also is a limitation due to the heterogeneity of factors that played a role throughout the period, such as different case definition criteria and changes in treatment guidelines, making it difficult to use the results to assess quality of care.

This descriptive study on initial treatment regimens at an HIV/AIDS reference center, albeit the difficulties posed by using secondary data, presents several results that allow means of comparison to data of other domestic and international groups. The results of the study also provide elements for developing more in depth research on the factors that play a role on patients with HIV/Aids undergoing treatment with ART.

Detailed follow-up including each regimen and periods of use, and survival of the cohort will be subject to future papers.

Acknowledgements: Contribution of each author: all authors contributed to the data analysis and writing of the present paper. Conflict of interest: None of the authors have any conflict of interest.

\section{References}

1. Guerreiro MF, Kerr-Pontes LRS, Mota RS, França Jr MC, Távora FF, Caminha L. Survival of Adult AIDS patients in a reference hospital of a metropolitan area in Brazil. Rev Saúde Pública 2001; 36(3): 278-84.

2. Marins JRP, Jamal LF, Chen SY, Barros MB, Hudes ES, Barbosa AA et al. Dramatic improvement in survival among adult Brazilian AIDS patients. AIDS 2003; 17(11): 1675-82.

3. Ministério da Saúde - Secretaria de Vigilância em Saúde - Programa Nacional de DST e Aids. Estudo de sobrevida de pacientes de AIDS no Brasil, 1998 a 1999 - Fase I Regiões Sul e Sudeste. Boletim Epidemiológico AIDS/DST $2008 ; 5(1)$.

4. Kalichman AO, Gianna MC, Basso CR, Santos NJS, Bueno SM, Chen S et al. Improvement of survival time among AIDS patients at STD/AIDS Training and Referral Center, São Paulo, Brasil. Annals of the XIV Int. AIDS Conference. Barcelona, July; 2002. p. 453.

5. Holcman MM, Ruiz EAC, Domingues CSB, Jamal LF, Rodrigues N, Santos NJS et al. Survival by age and sex after diagnosis of AIDS in a referral center, São Paulo, Brazil. Annals of the XV Int. AIDS Conference. Bangkok, July 11-16; 2004.
6. Kalichman AO, Gianna MC, Bueno SM, Basso CR, Ruiz EAC, Tayra A et al. Survival among AIDS patients by situations before and after HAART availability at the STD/Aids Training and Referral Center (CRT-DST/ AIDS SP), São Paulo, Brazil. Annals of the XV Int. AIDS Conference. Bangkok, July 11-16; 2004.

7. Egger M, May M, Chêne G, Phillips AN, Ledergerber B, Dabis F et al. Prognosis of HIv-1-infectes patients starting highly active antiretroviral therapy: a collaborative analysis of prospective studies. The Lancet 2002; 360: 119-29.

8. When to Start Consortium. Timing of initiation of antiretroviral therapy in AIDS-free HIV-1-infected patients: a collaborative analysis of 18 HIV cohort studies. The Lancet 2009; 373: 1352-62.

9. Weniger BG, Quinhões EP, Sereno AB, de Perez MA, Krebs JW, Ismael C et al. A simplified surveillance case definition of AIDS derived from empirical clinical data. The Clinical AIDS Study Group, and the Working Group on AIDS case definition. J Acquir Immune Defic Syndr 1992; 5(12): 1212-23. 
10. The Antiretroviral Therapy (ART) Cohort Collaboration. Prognosis of HIV-1- infected patients up to 5 years after initiation of HAART: collaborative analysis of prospective studies. AIDS 2007; 21(9): 1185-97.

11. Lemly DC, Shepherd BE, Hulgan T, Rebeiro P, Stinnette S, Blackwell RB et al. Race and Sex Differences in Antiretroviral Therapy Use and Mortality among HIVInfected Persons. J Infec Dis 2009; 199: 991-8.

12. Braga P, Cardoso, MRA, Segurado AC. Gender Differences in Survival in an HIV/AIDS Cohort from São Paulo, Brazil. Aids Patient Care and STDs 2007; 21(5): 321-9.

13. Campos DP, Ribeiro SR, Grinsztejun B, Veloso VG, Valente JG, Bastos FI et al. Survival of AIDS Patients using two case definitions, Rio de Janeiro, Brazil. 19862003. AIDS 2005, 19(S4): S22-S26.

14. Malta M, Bastos FI, Silva CMFP, Pereira GFM, Lucena FFA, Fonseca MGP et al. Differential survival benefit of universal HAART access in Brazil: a nation-wide comparison of injecting drug users versus men who have sex with men. J Acquir Immune Defic Syndr 2009; 52(5): 629-35.
15. Malta M, Magnanini MMF, Strathdee SA, Bastos FI. Adherence to anitretroviral therapy among hiv-infected drug users: a meta-analysis. AIDS Behav 2010; 14: 73147.

16. Ministério da Saúde - Secretaria de Vigilância em Saúde - Programa Nacional de DST e AIDS. Recomendações para Terapia Anti-retroviral em Adultos e Adolescentes Infectados pelo HIV. Disponível em http://www.aids.gov. br. [Acessado em 3 de setembro de 2010].

17. Mussini C, Manzardo C, Johnson M, Monforte A d'A, Uberti-Foppa C, Antinori et al. Patients presenting with AIDS in the HAART era: a collaborative cohort analysis, AIDS 2008; 22(18): 2461-9.

18. Medeiros R, Diaz RS, Castelo Filho A. Estimating the Length of the First Antiretroviral Therapy Regiment Durability in São Paulo, Brazil. Braz J Infect Dis 2002; 6(6): 298-304.

19. Schneider MF, Gange SJ, Willians CM, Anastos K, Greenblatt RM, Kingsley L et al. Patterns of the hazard of death after AIDS through the evolution of antiretroviral therapy: 1984-2004. AIDS 2005; 19: 2009-18.

Recebido em: 26/05/10

Versão final reapresentada em: 10/09/10

Aprovado em: 29/09/10 